\title{
Supplemental materials.
}

Nanotube synthesis. Before deposition of the protein nanotubes into the pores of the alumina template membrane, a thin $(\sim 5 \mathrm{~nm})$ layer of gold was sputtered onto each membrane face. As discussed in the text of the Nano Letters paper, this retards film formation at the membrane faces so that the pores do not get blocked. A monolayer of 3-amino propylphosphonic acid (APA) is deposited first by immersing the membrane into $5 \mathrm{mM}$ APA ( $\mathrm{pH} \mathrm{5.8)}$ for $24 \mathrm{hr}$. The phosphate end of APA adsorbs to the pore wall. The amino end of APA is then reacted with glutaraldehyde (GA) by immersing the membrane into a $2.5 \%$ GA aqueous solution for $12 \mathrm{~h}$. After rinsing with water and $\mathrm{pH}=7$ phosphate buffer solution (PBS), the membrane is inserted into a Millipore vacuum filter system. $10 \mathrm{~mL}$ of a $10 \mathrm{mg} / \mathrm{mL}$ protein solution in PBS is slowly passed through the alumina membrane. After rinsing carefully with PBS, the membrane is immersed in another PBS solution containing $0.025 \%$ GA and incubated for $12 \mathrm{hr}$. The membrane is then treated to a second vacuum filtration step to deposit the next protein layer, etc.

Liberating the Nanotubes. First, the nanotube-containing membrane is immersed in $5 \%$ phosphoric acid solution at $0{ }^{\circ} \mathrm{C}$ for one hour. This "preexposure" causes the Au surface films to delaminate, and they are carefully peeled away from the surface of the template membrane. The alumina membrane is then immersed in fresh $5 \%$ phosphoric acid solution at $0{ }^{\circ} \mathrm{C}$ for 24 $\mathrm{hr}$, resulting in complete dissolution of the membrane. The liberated nanotubes are then collected by filtration using a nanopore polycarbonate filter with nominally $50 \mathrm{~nm}$-diameter pores.

Assaying the Glucose Oxidase (GOD) Activity. The assay is performed in 15 $\mathrm{ml}$ PBS containing $13 \mathrm{mM}$ phenol, $0.7 \mathrm{mM}$ 4-aminophenazone, $0.1 \mathrm{M}$ glucose and 10 units of peroxidase (POD). The start time begins immediately after the alumina membrane or the GOD nanotubes are immersed into the above solution. The mixture was incubated at $37^{\circ} \mathrm{C}$ for $5 \mathrm{~min}$. Glucose is oxidized by the GOD ultimately to gluconic acid with the liberation of hydrogen peroxide, which is converted into water and oxygen by the enzyme POD. 4-aminophenazone, an 
oxygen acceptor, takes up the oxygen and together with phenol forms a pink colored chromogen, which can be detected at $515 \mathrm{~nm}$. One unit of the GOD was defined as the amount of enzyme producing $1 \mu \mathrm{mol}$ of $\mathrm{H}_{2} \mathrm{O}_{2}$ per min at $37^{\circ} \mathrm{C}$. The absorption measurements were performed with an 845x UV-visible system (Aligent technologies).

Immobilization of the $\mathrm{Hb}$ nanotubes onto the ITO electrode. The ITO glass electrode $(5 \mathrm{~mm} \times 5 \mathrm{~mm}$ ) is first modified with triethoxysilylbutyraldehyde. The pendant aldehyde groups are then reacted with the amino groups of APA by immersion of the electrode into $5 \mathrm{mM}$ APA solution dissolved in $\mathrm{pH} 5.8$ buffer solution. The electrode was immersed into this solution for $12 \mathrm{hr}$. This leaves pendant phosphonate groups from the APA on the surface. These are reacted with $\mathrm{Zr}(\mathrm{IV})$ by immersion of the electrode into $20 \mathrm{ml}$ of $0.05 \mathrm{M} \mathrm{ZrOCl}_{2}$ for $3 \mathrm{hr}$. The outer surface of the $\mathrm{Hb}$ nanotubes contain pendant phosphonate groups because the first layer of material deposited on the pore walls is APA. The phosphonates on the outer surface of the $\mathrm{Hb}$ nanotubes are reacted with the $\mathrm{Zr}(\mathrm{IV})$ sites on the ITO electrode surface. This was accomplished by immersing the electrode into a suspension containing $\sim 3 \mathrm{mg}$ of nanotubes per $\mathrm{mL}$ of solution. Cyclic voltammetry was performed on an E\&EG Potentiostat/Galvanostat Model 273 in PBS, with the nanotube-modified ITO as the working electrode, a platinum foil as the counter electrode and a $\mathrm{Ag} / \mathrm{AgCl}$ electrode as the reference. 